\title{
Application of Iraqi Natural Rich-Bauxite Mineral Clays doped with Chromium Oxides in Upgrading of Iraqi Kerosene
}

\author{
R. A. Buker \\ M. Kh. Al-Rashidi \\ O. M. Ramadhan \\ Department of chemistry / College of Education \\ University of Mosul
}

\author{
Received
}

29 / $01 / 2012$
Accepted

03 / 04 / 2012

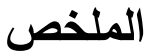

تم تطعيم اتربة معدنية عراقية طبيعية غنية بمعدن البوكسايت بخليط من اكاسيد الكروم.

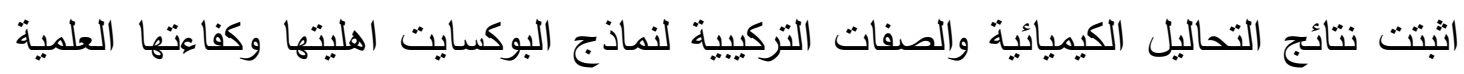

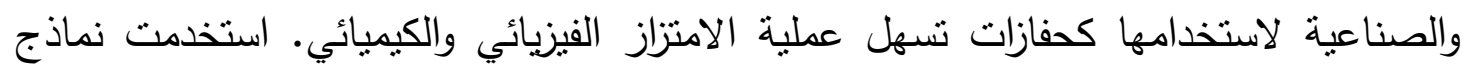

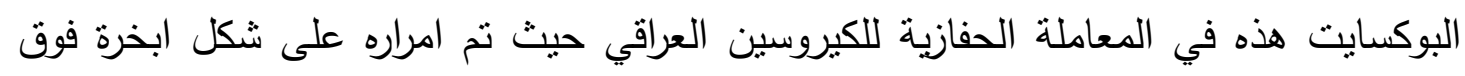
الحفاز الموجود في فرن اسطواني مسخن بدرجات حرارية تتراوح بين 300-475 درجة مئوية,

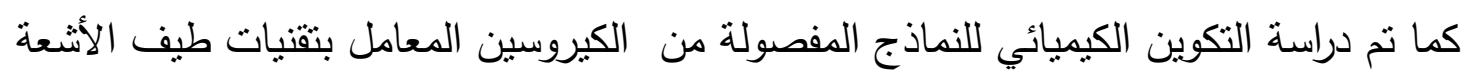

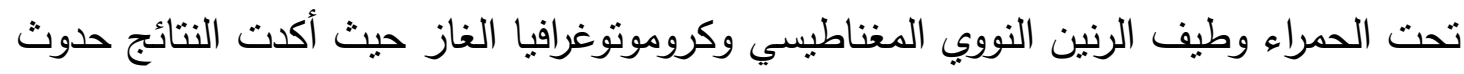

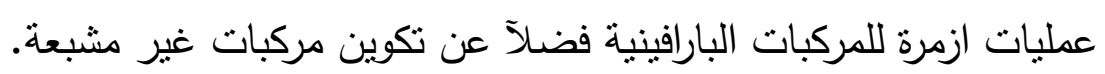

\section{Abstract}

Iraqi Natural rich-bauxite mineral clay samples were doped by mixed chromium oxides. The observed chemical composition and structural properties of the above samples evaluate their scientific and economic utilization as adsorbent material catalysts. They have been applied in catalytic treatment of Iraqi kerosene which was conducted by feeding the kerosene in gaseous phase over the catalyst using tube furnace heated in the range of $300-475^{\circ} \mathrm{C}$. Infrared, nuclear magnetic resonance spectra and gas chromatography techniques have been used to study the chemical composition of the separated fractions. The results revealed that some isomerization and hydrogen removal processes were occurred.

\section{Introduction:}

Kerosene is the part which distilled from the crude oil between $160-250^{\circ} \mathrm{C}$ and contain in its chemical composition $23 \%$ straight paraffins, $16 \%$ branched paraffins,32\% mononuclear naphthenics, $11 \%$ 
poly nuclear naphthenics, $15 \%$ mononuclear aromatics, and 3\% poly nuclear aromatic hydrocarbons ${ }^{(1)}$. Catalytic activity on such kerosene above $300^{\circ} \mathrm{C}$ might catalyzed some isomerization and cracking reactions in addition to the removal of hydrogen and conversion to naphthenic and aromatic hydrocarbons which could be separated and used in the petrochemical industries ${ }^{(2)}$. On the other hands, it is well known that mineral clay is one of so many catalysts to deal with the above activities ${ }^{(3)}$. They are very stable during catalytic treatment processes and have a surface endowed with weakly acidic and basic sites.

Bauxite is considered to be one of the important mineral clays naturally occurring in the world, and fortunately it was reported that bauxite-rich rocks occurred naturally in large masses around Al-Anbar city/west of $\operatorname{Iraq}^{(4)}$. In general, bauxite consist from mixed heterogeneous minerals like: Gibbsite $\left(\mathrm{Al}(\mathrm{OH})_{3}\right)$, Boehmite $(\mathrm{AlO}(\mathrm{OH}))$, Dispor $(\mathrm{AlOOH})$, in addition to small quantities of Hematite $\left(\mathrm{Fe}_{2} \mathrm{O}_{3}\right)$, Magnetite $\left(\mathrm{Fe}_{3} \mathrm{O}_{4}\right)$, Anatase $\left(\mathrm{TiO}_{2}\right)$, Rutile $\left(\mathrm{TiO}_{2}\right)$, Halloysite $\left(\mathrm{Al}_{2} \mathrm{O}_{3}, 2 \mathrm{SiO}_{2} .2 \mathrm{H}_{2} \mathrm{O}\right)$, Kaolinite $\left(\mathrm{Al}_{2} \mathrm{Si}_{2} \mathrm{O}_{5}(\mathrm{OH})_{4}\right)$, and Quartz $\left(\mathrm{SiO}_{2}\right)^{(5)}$. Moreover, it was reported that such rocks called Bauxite after Ditter ${ }^{(6)}$ since it is bearing in its chemical composition between $55-65 \%$ from aluminum oxides and less than $30 \%$ of silica.

Application of Iraqi raw minerals in petroleum industries as adsorbent materials was the interest of many workers. Several works were reported in this field recently ${ }^{(7-9)}$ investigating heavy crude oils since Iraq is considered as one of the important countries in the world in term of petroleum resources ${ }^{(10)}$.

As a continuation of these studies the present study is considered to investigate bauxite sample from Al-Hussaniate area at Al-Anbar governorate/Iraq, which is expected to be rich in aluminum oxides. Purification and grafting of this sample supposed to create, stable, active and selective catalyst employed in catalytic treatment and upgrading of Iraqi kerosene ${ }^{(11)}$.

\section{Experimental}

\section{A- Sources and collection of samples:}

Natural minerals clay, obtained from area around Al-Hussainiat at Al-Anbar governorate/Iraq, were purified from carbonate and bicarbonate compounds chemically by $25 \% \mathrm{HCl}$ and used as a natural clay samples. These samples were pale yellow in color have (120-150 mesh ASTM). Individual samples weighed from 1.0 to $3.0 \mathrm{~kg}$; and were thoroughly mixed before their coning and quartering to obtain representative samples. At each sampling site, parent rock, samples were also collected. For x-ray diffraction analysis and bulk mineralogy, the raw sample was powdered by agate mortar and agate tama mill. 
Meanwhile, the kerosene sample, which was obtained from local petrol station (Mosul city/Iraq) in order to be dry and clean,was further dried by $\mathrm{CaCl}_{2}$ drying agent.Mixed oxides of $\left(\mathrm{CrO}_{3} \& \mathrm{Cr}_{2} \mathrm{O}_{3}\right)$ were obtained via heating $\mathrm{CrO}_{3}$ at $260^{\circ} \mathrm{C}$ for two hours ${ }^{(12)}$.

\section{B- Methods of study:}

The identification of clay minerals and their alteration products was carried out by the power diffraction method, which carried out using Phillips X-ray diffraction equipment model $\mathrm{pw} / 1710$ with monochromatic, Cu-radiation $\left(\lambda=1.54178 \mathrm{~A}^{\circ}\right)$ at $40 \mathrm{k} . \mathrm{v}, 35 \mathrm{~m} . \mathrm{A}$. and scanning speed $0.02^{\circ} \mathrm{sec}$. were used. The reflection peaks between $2 \theta=2^{\circ}$ and $60^{\circ}$, corresponding spacing $\left(\mathrm{d}, \mathrm{A}^{\circ}\right)$ and relative intensities $\left(\mathrm{I} / \mathrm{I}^{\circ}\right)$ were obtained. The diffraction charts and relative intensities are obtained and compared with ICDD files. Meanwhile x-ray fluorescence spectrophotometer was employed for natural clays on Phillips/PW 2404 analysis and the absorption spectra were recorded on FTIR 4100 JASCO spectrophotometer using $\mathrm{KBr}$ disk ${ }^{(13)}$.

The thermal analysis was by means of Schimadzu DTA-50H, and TGA-50H. Each powdered sample was heated by $10^{\circ} \mathrm{C} / \mathrm{min}$. up to $1100^{\circ} \mathrm{C}$ with $\alpha-\mathrm{Al}_{2} \mathrm{O}_{3}$ as a reference material. Temperature, weight change in wt., and the thermal behavior of the sample is recorded on the chart.

On the other hand, the isolated fractions from kerosene also studied and the absorption spectra were recorded on the above IR instrument using $\mathrm{NaCl}$ cell. Meanwhile, NMR data were obtained from Shimadzu GcMs-Qp-1000EX Mass Spectrometer at 70 e.v 75.46 MHZ, GC from Perkin Elmer ArNEI Clarus 500 Gas Chromatography, and CHNS from Automatic CHNS analyzer Elemental Vario EL III.

The above technical studies were performed at ministry of petroleum, the Egyptian mineral resources authority, central laboratory sector/ Egypt.

\section{C- Application:}

The prepared mixed metal oxides sample $\left(\mathrm{Cr}_{\mathrm{x}} \mathrm{O}_{\mathrm{y}}\right)$ was supported over purified bauxite sample by impregnation grafting method ${ }^{(14)}$ and further dried and activated at $550^{\circ} \mathrm{C}$. The prepared catalyst finally employed in catalytic treatment of kerosene under investigation which was conducted by feeding the kerosene in gas phase over the catalyst using tube furnace. The employed temperatures for such processes were $\left(300-475^{\circ} \mathrm{C}\right)$ in addition to five runs at $475^{\circ} \mathrm{C}$. The parent and treated kerosene fractions were further studied by separating the paraffinic content using urea adduction method. IR, NMR, and GC techniques were employed to study the chemical nature of the separated stuff to evaluate the adsorption activity and selectivity of the investigated samples. 


\section{Results and Discussion:}

Physical characterization, structural, and chemical analysis of natural bauxite, bauxite heated at $700^{\circ} \mathrm{C}$, and the doped samples were studied and reported recently ${ }^{(15)}$. In general, it seems that all those samples show a significant variations in their chemical compositions, physical properties, and especially in their structural components. It is therefore of interest to get benefit of such foundations which evaluate the studied bauxite samples as a good adsorbents in the catalytic treatment processes $^{(3)}$. However, in our investigation we thought that it is of interest to concentrate the catalytic activity on the doped sample, so it was employed in upgrading of Iraqi kerosene $\left(165-250^{\circ} \mathrm{C}\right)$ fraction.

On referring to the previous studies ${ }^{(8,9,11)}$, it seems that separation of the paraffinic content from the whole samples under investigation by means of urea adduct method and studying their CHNS elemental analysis yield naphthenic and aromatic hydrocarbons, Table(1). Such result occurred on catalytic treatment in the range $450-500^{\circ} \mathrm{C}$ via the hydrogen removal and conversion processes. To prove such proposed results, chemical characteristic nature of the isolated fractions have been investigated via infrared, nuclear magnetic resonance, and gas chromatography techniques. Infrared data which are presented in Table (2) related to the all studied isolated paraffinic fractions. It is obviously clear that the absorption bands at 1377 and $2855 \mathrm{~cm}^{-1}$ attributed to the bending and stretching vibrations of methyl groups respectively ${ }^{(13)}$. Absorption bands at $1463-1459 \mathrm{~cm}^{-1}$ and at $2925 \mathrm{~cm}^{-1}$ related to the bending and stretching vibrations of methylene $\mathrm{C}-\mathrm{H}$ respectively, which became less intensive. Finally, it seems that bands at $1608-1607 \mathrm{~cm}^{-1}$ and at $1541 \mathrm{~cm}^{-1}$ respect the aromatic C-C bond, in addition to 722, 740, 767, $806,1021 \mathrm{~cm}^{-1}$ which represent the bending of C-H outside the aromatic ring ${ }^{(16)}$. These bands seemed to be medium in intensity with more treatment processes.

Such results should be confirmed by nuclear magnetic resonance studies which have been employed for the untreated kerosene, and samples which have been treated at $300,400,475^{\circ} \mathrm{C}$ only, Figures (1-3). Interpretation of these data has to be depending on the area measured under the curves of the absorption protons ${ }^{(17)}$. Table(3) show the obtained results which include aromatic hydrogen $(\mathrm{Ha})$, benzylic hydrogen $(\mathrm{H} \alpha)$, naphthenic hydrogen(Hn),methylene hydrogen (Hmy), and paraffinic methyl hydrogen (Hme). On comparing these kinds of hydrogen with each others, the results indicate that doping bauxite materials with chromium oxides clarified them to be a good catalyst for isomerization of paraffinic compounds at low temperature $\left(300-400^{\circ} \mathrm{C}\right)$. Meanwhile, at $475^{\circ} \mathrm{C}$, it seems that removal of hydrogen and conversion to oleffinic compound occurred and definitely such observation can be confirmed by measuring the bromine number factor. It was found that the bromine number for the untreated kerosene was nil, changed to 0.195 for sample treated at $475^{\circ} \mathrm{C}^{(2)}$. On repeating this treatment process five times, it was found that more naphthenic and aromatic hydrocarbons were formed, Table(4) ${ }^{(17) .}$ 
Finally, it is well known that hydrocarbon compounds are present in petroleum fractions in a very complicated nature, therefore, workers studied the possibility of their separation and identification by gas chromatography technique ${ }^{(18,19)}$. Accordingly, GC was employed on kerosene samples and the computerized results are presented in Table(5), in addition to one of so many figures selected to be for parent kerosene, Figure(4). The results again reflect the isomerization process in addition to conversion to naphthenic and aromatic compounds, especially at $475^{\circ} \mathrm{C}$ treatment whereas it was seen that paraffinic compounds percentage changed from 26.6 to $8.62 \%$.

\section{References}

1) G. D. Hobson, "Modern Petroleum Chemistry and Technology", John Wiley and Sons, New York, USA, (1988).

2) Y. L. Lam, "Cracking Catalyst Composition", Abs. US Patent, No. 0165083 Al., (2002).

3) R. B. Gillespie, "Isomerization Catalyst and Processes", Abs. US Patent, No. 0249231, (2004).

4) P. A. Plunkert, "Bauxite and Alumina", US Geological Survey, (2006).

5) E. L. Bray, "Bauxite and Alumina: Statistics and Information", US Geological Survey, (2007).

6) A. M. Batman, "Economic Mineral Deposits", $2^{\text {nd }}$ ed. John Wiley and Sons, New York, (1978).

7) R. A. Buker, and M. Z. Hamoodat, To be published in J. Sci. \& Educ., (2012).

8) R. A. Buker and A. S. Al-Botani, J. Edu. \& Sci., the First Conference on Chemistry, October (2008).

9) O. M. Ramadhan, E. A. Al- Hyali, and K. S. Tawfique, J. Sci. Educ., Vol. 45, p,29, (2000).

10) O. M. Ramadhan and R. Y. Ghazal, National J. Chem., Vol. 16, 43 (2004).

11) K. A. Al-M'mari, M. Sc. Thesis, University of Mosul, Iraq, (1999).

12) B. Liu, and M. Terano, J. Molec. Cat. Chem.,172, p,227, (2001).

13) B. Stuart, "Infrared Spectroscopy: Fundamentals and Applications", John Wiley and Sons, (2004).

14) W. C. Fernalius, "Inorganic Synthesis", Vol. II, Mc Graw-Hill Book Company, London, (1946).

15) R. A. Buker, M. Kh. Al-Rashidi, and O.M. Ramadhan, (To be published in 2012).

16) D. Williams and I. Fleming. "spectroscopic methods of inorganic chemistry", $4^{\text {th }}$ ed. MeGraw-Hill Book comp. Ltd., London (1981).

17) G. Gauglitz and T. Vo-Dinh, "Hand book of Spectroscopy", John Wiley and Sons, (2003).

18) Agilent in Gas Chromatography, (http/:www.chem.agilent.com/cag/cabu/whtisgc.htm), (2006).

19) V. G. Berezkin, and Y. S. Drugov, "Gas Chromatography in Air Pollution Analysis", Review of Journal Chromatography Library, Vol. 49, p,1, (2007). 
Application of Iraqi Natural Rich-Bauxite Mineral Clays doped with ...

Table 1:Elemental analysis of untreated kerosene and treated at different temperatures.

\begin{tabular}{|c|c|c|c|c|c|c|}
\hline \multirow{2}{*}{ Sample } & \multirow{2}{*}{$\begin{array}{c}\text { \% Calculate } \\
\text { Paraffin }\end{array}$} & \multirow{2}{*}{$\begin{array}{c}\text { \%Paraffin } \\
\text { from GC }\end{array}$} & \multicolumn{4}{|c|}{ \%CHNS } \\
\cline { 5 - 8 } & & & $\mathrm{C}$ & $\mathrm{H}$ & $\mathrm{N}$ & $\mathrm{S}$ \\
\hline Untreated Kerosene & 25.8 & 26.6 & 81.81 & 18.00 & Nil & Nil \\
\hline 300 & 25.13 & 25.6 & & & & \\
\hline 350 & 35.98 & 25.2 & & & & \\
\hline 400 & 33.112 & 27.4 & & & & \\
\hline 450 & 20.673 & 25.11 & & & & \\
\hline 475 & 21.066 & 23.934 & 83.38 & 16.50 & Nil & Nil \\
\hline & & & & & \\
\hline
\end{tabular}

Table 2: Infrared data of untreated kerosene and treated five times.

\begin{tabular}{|c|c|c|c|c|c|c|c|c|c|c|c|c|c|c|c|}
\hline Part & & & & & & & Absc & bance & $\left.m^{-1}\right)$ & & & & & & \\
\hline $\begin{array}{l}\text { Untreated } \\
\text { kerosene }\end{array}$ & $\begin{array}{c}2957 \\
5\end{array}$ & $\begin{array}{c}2926 \\
5\end{array}$ & $\begin{array}{c}2855 \\
5\end{array}$ & $\begin{array}{c}1608 \\
w\end{array}$ & - & - & $\begin{array}{c}1464 \\
5\end{array}$ & $\begin{array}{c}1377 \\
5\end{array}$ & $\begin{array}{c}1032 \\
w\end{array}$ & - & $\begin{array}{c}805 \\
w\end{array}$ & - & $\begin{array}{c}766 \\
w\end{array}$ & - & $\begin{array}{c}722 \\
w\end{array}$ \\
\hline Treated-1 & $\begin{array}{c}2957 \\
5\end{array}$ & $\begin{array}{c}2925 \\
5\end{array}$ & $\begin{array}{c}2855 \\
5\end{array}$ & $\begin{array}{c}1608 \\
w\end{array}$ & $\begin{array}{c}1541 \\
w\end{array}$ & $\begin{array}{c}1506 \\
w\end{array}$ & $\begin{array}{c}1463 \\
5\end{array}$ & $\begin{array}{c}1377 \\
\mathrm{~m}\end{array}$ & $\begin{array}{c}1033 \\
w\end{array}$ & $\ldots$ & $\begin{array}{c}805 \\
w\end{array}$ & $\cdots$ & $\begin{array}{c}766 \\
w\end{array}$ & $\ldots$ & $\begin{array}{c}722 \\
w\end{array}$ \\
\hline Treated-2 & $\begin{array}{c}2957 \\
5\end{array}$ & $\begin{array}{c}2925 \\
5\end{array}$ & $\begin{array}{c}2855 \\
5\end{array}$ & $\begin{array}{c}1607 \\
w\end{array}$ & $\begin{array}{c}1541 \\
w\end{array}$ & $\begin{array}{c}1506 \\
w\end{array}$ & $\begin{array}{c}1463 \\
5\end{array}$ & $\begin{array}{c}1377 \\
\mathrm{~m}\end{array}$ & $\begin{array}{c}1033 \\
w\end{array}$ & $\begin{array}{c}889 \\
w\end{array}$ & $\begin{array}{c}805 \\
w\end{array}$ & $\ldots$ & $\begin{array}{c}767 \\
w\end{array}$ & $\ldots$ & $\begin{array}{c}722 \\
w\end{array}$ \\
\hline Treated-3 & $\begin{array}{c}2957 \\
5\end{array}$ & $\begin{array}{c}2925 \\
5\end{array}$ & $\begin{array}{c}2855 \\
5\end{array}$ & $\begin{array}{c}1607 \\
w\end{array}$ & $\ldots$ & $\begin{array}{c}1506 \\
w\end{array}$ & $\begin{array}{c}1463 \\
5\end{array}$ & $\begin{array}{c}1377 \\
5\end{array}$ & $\begin{array}{c}1021 \\
w\end{array}$ & $\begin{array}{c}908 \\
w\end{array}$ & $\begin{array}{c}806 \\
w\end{array}$ & $\ldots$ & $\begin{array}{c}767 \\
w\end{array}$ & $\begin{array}{c}740 \\
w\end{array}$ & $\begin{array}{c}722 \\
w\end{array}$ \\
\hline Treated-4 & $\begin{array}{c}2957 \\
5\end{array}$ & $\begin{array}{c}2925 \\
\mathrm{~m}\end{array}$ & $\begin{array}{c}2855 \\
5\end{array}$ & $\begin{array}{c}1607 \\
w\end{array}$ & $\begin{array}{c}1541 \\
m\end{array}$ & $\begin{array}{c}1506 \\
m\end{array}$ & $\begin{array}{c}1459 \\
5\end{array}$ & $\begin{array}{c}1377 \\
5\end{array}$ & $\begin{array}{c}1021 \\
w\end{array}$ & $\begin{array}{c}846 \\
m\end{array}$ & $\begin{array}{c}806 \\
m\end{array}$ & $\begin{array}{c}782 \\
m\end{array}$ & $\begin{array}{c}767 \\
w\end{array}$ & $\begin{array}{c}740 \\
w\end{array}$ & $\begin{array}{c}722 \\
w\end{array}$ \\
\hline Treated-5 & $\begin{array}{c}2957 \\
5\end{array}$ & $\begin{array}{c}2925 \\
m\end{array}$ & $\begin{array}{c}2855 \\
S\end{array}$ & $\begin{array}{c}1607 \\
w\end{array}$ & $\begin{array}{c}1541 \\
m\end{array}$ & $\begin{array}{c}1506 \\
w\end{array}$ & $\begin{array}{c}1463 \\
m\end{array}$ & $\begin{array}{c}1377 \\
w\end{array}$ & $\begin{array}{c}1033 \\
w\end{array}$ & $\begin{array}{c}908 \\
m\end{array}$ & $\begin{array}{c}806 \\
m\end{array}$ & $\begin{array}{c}781 \\
m\end{array}$ & $\begin{array}{c}767 \\
m\end{array}$ & $\begin{array}{c}740 \\
m\end{array}$ & $\begin{array}{c}723 \\
w\end{array}$ \\
\hline
\end{tabular}

Table 3: NMR data of untreated kerosene and treated at different temperatures.

\begin{tabular}{|c|c|c|c|c|c|}
\hline Sample & $\% \mathrm{H} \mathrm{a}$ & $\% \mathrm{H} \boldsymbol{\%}$ & $\% \mathrm{H} \mathrm{n}$ & $\% \mathrm{H} \mathrm{my}$ & $\% \mathrm{H}$ me \\
\hline $\begin{array}{c}\text { Untreated } \\
\text { kerosene }\end{array}$ & 13.74 & 15.12 & 16.72 & 42.08 & 12.34 \\
\hline $300^{\circ} \mathrm{C}$ & 9.55 & 11.63 & 18.97 & 39.11 & 20.30 \\
\hline $400^{\circ} \mathrm{C}$ & 9.09 & 9.12 & 27.92 & 29.08 & 24.72 \\
\hline $475^{\circ} \mathrm{C}$ & 13.75 & 17.44 & 14.19 & 44.59 & 10.04 \\
\hline
\end{tabular}


R. A. Buker \& M. Kh. Al-Rashidi \& O. M. Ramadhan

Table 4: NMR data of untreated kerosene and treated five times.

\begin{tabular}{|c|c|c|c|c|c|}
\hline Sample treated at 475 & \% $\mathbf{~ a ~}$ & \% $\mathbf{~} \boldsymbol{\%}$ & \% $\mathbf{~ n}$ & \% $\mathbf{~ m y}$ & \% $\mathbf{~ m e ~}$ \\
\hline $\begin{array}{c}\text { Untreated } \\
\text { kerosene }\end{array}$ & 13.75 & 15.12 & 16.72 & 42.08 & 12.34 \\
\hline Treated-1 & 20.60 & 18.01 & 12.10 & 28.85 & 20.42 \\
\hline Treated-2 & 22.62 & 20.28 & 16.99 & 25.70 & 14.40 \\
\hline Treated-3 & 24.69 & 19.97 & 12.49 & 26.61 & 16.28 \\
\hline Treated-4 & 27.52 & 23.37 & 12.15 & 21.51 & 15.44 \\
\hline Treated-5 & 28.02 & 18.96 & 12.51 & 21.77 & 18.66 \\
\hline
\end{tabular}

Table 5: Gas chromatography data of untreated kerosene and treated five times.

\begin{tabular}{|c|c|c|c|c|c|c|c|}
\hline \multirow{2}{*}{ Part } & \multirow{2}{*}{$\begin{array}{c}\text { Retention } \\
\text { time R.T }\end{array}$} & \multirow{2}{*}{$\begin{array}{c}\text { Untreated } \\
\text { Kerosene }\end{array}$} & \multicolumn{5}{|c|}{ Treated Kerosene at 475 C० } \\
\cline { 5 - 8 } & 10.2 & 1.578 & 1.117 & 1.190 & 0.651 & 1.074 & 1.033 \\
\hline C8 & 12.0 & 3.154 & 2.441 & 2.449 & 2.300 & 2.323 & 2.262 \\
\hline C9 & 17.8 & 5.730 & 5.879 & 5.701 & 5.090 & 4.911 & 5.237 \\
\hline C10 & 24.9 & 6.341 & 6.008 & 5.906 & 5.200 & 4.625 & 4.830 \\
\hline C11 & 32.2 & 5.050 & 4.709 & 4.423 & 3.677 & 3.334 & 3.414 \\
\hline C12 & 39.5 & 3.587 & 3.239 & 3.665 & 2.410 & 2.123 & 2.168 \\
\hline C13 & 46.5 & 1.149 & 1.668 & 1.645 & 1.435 & 1.354 & 1.502 \\
\hline C14 & 54.3 & 0.068 & 0.322 & 0.471 & 0.652 & 0.762 & 0.999 \\
\hline C15 & 26.597 & 25.183 & 25.450 & 21.211 & 20.506 & 21.445 \\
\hline Total & & 21.31 & 23.93 & 20.34 & 15.80 & 9.82 & 8.62 \\
\hline $\begin{array}{c}\text { Paraffin \& } \\
\text { Calculated \% }\end{array}$ & & 78.9 & 75.96 & 79.66 & 84.20 & 91.18 & 91.38 \\
\hline $\begin{array}{c}\text { Aromatic \& } \\
\text { naphthenic \% }\end{array}$ & & & & & & & Treated-2 \\
\hline
\end{tabular}

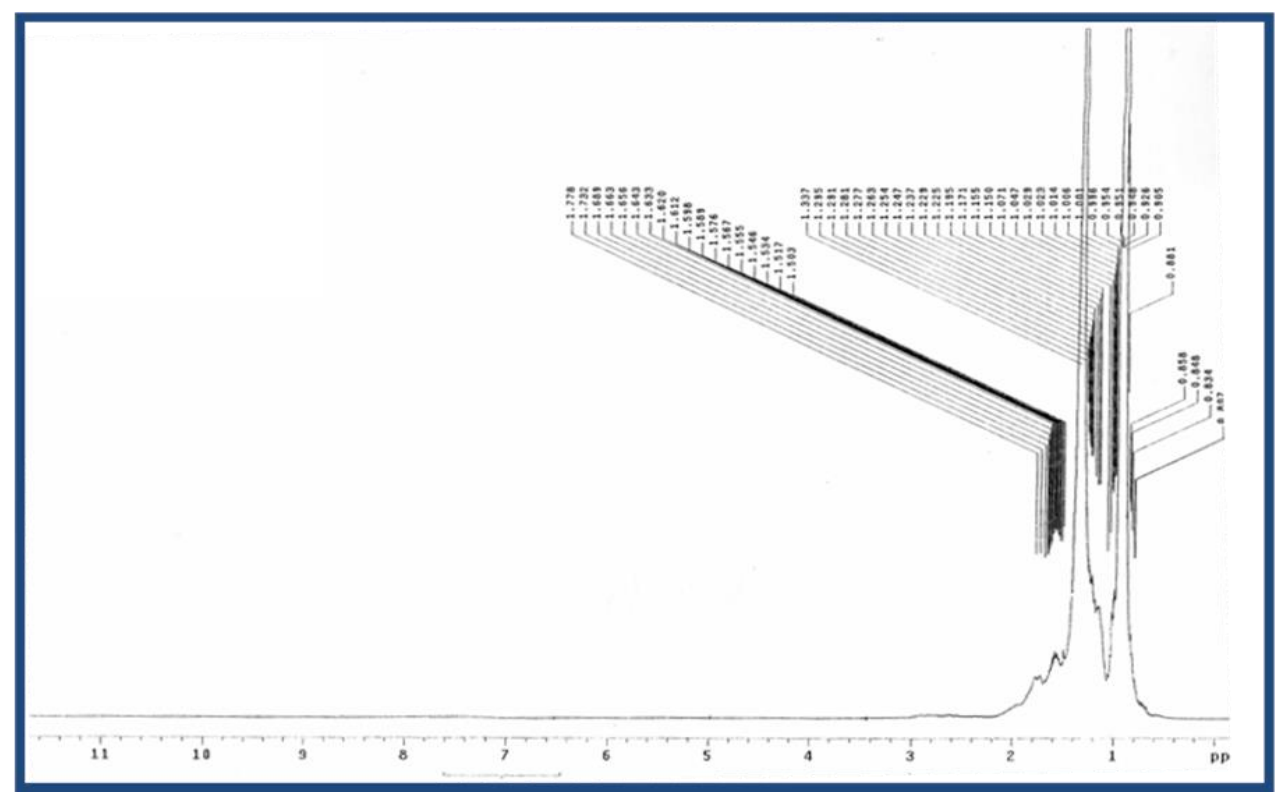

Figure 1: ${ }^{1} \mathrm{H}$ NMR spectra of the treated kerosene at $300^{\circ} \mathrm{C}$. 
Application of Iraqi Natural Rich-Bauxite Mineral Clays doped with ...

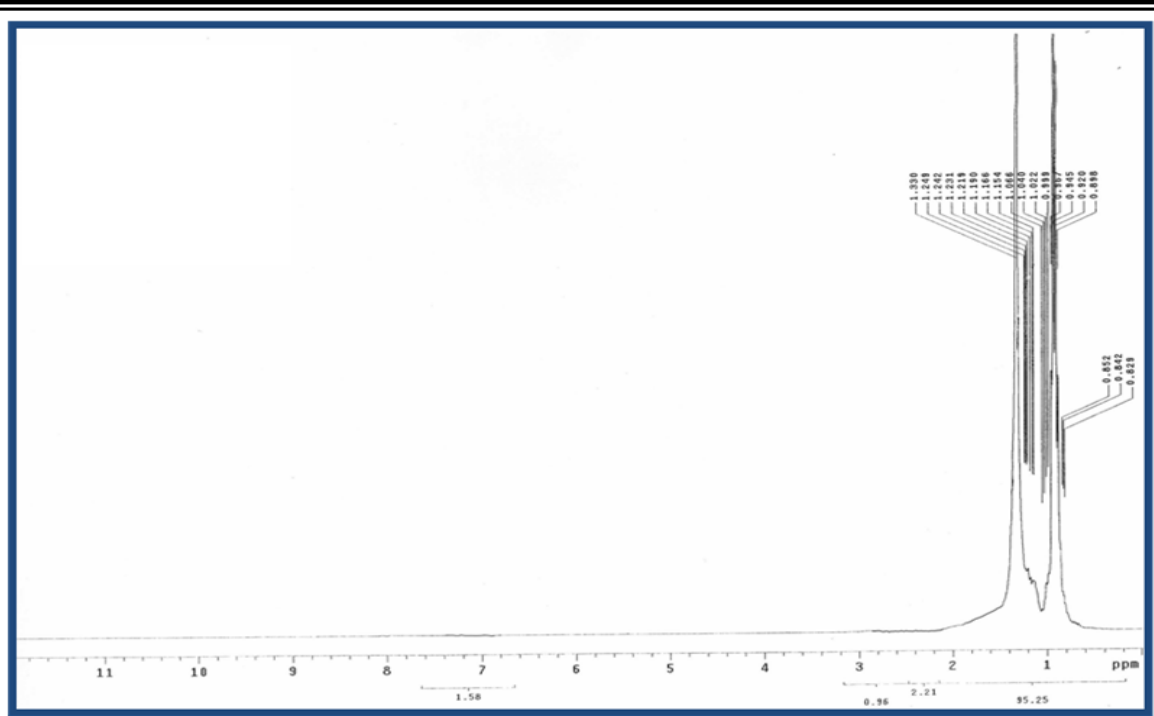

Figure 2: ${ }^{1} \mathrm{H}$ NMR spectra of the kerosene treated at $400^{\circ} \mathrm{C}$.

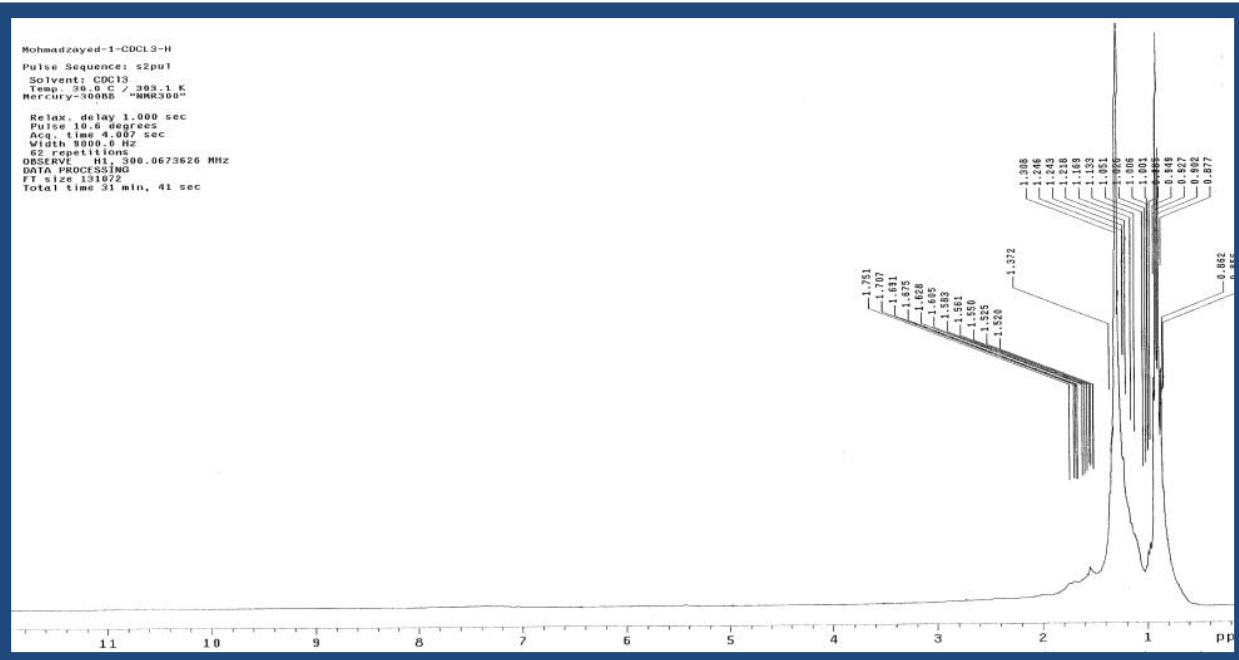

Figure 3: ${ }^{1} \mathrm{H}$ NMR spectra of the treated kerosene at $475^{\circ} \mathrm{C}$.

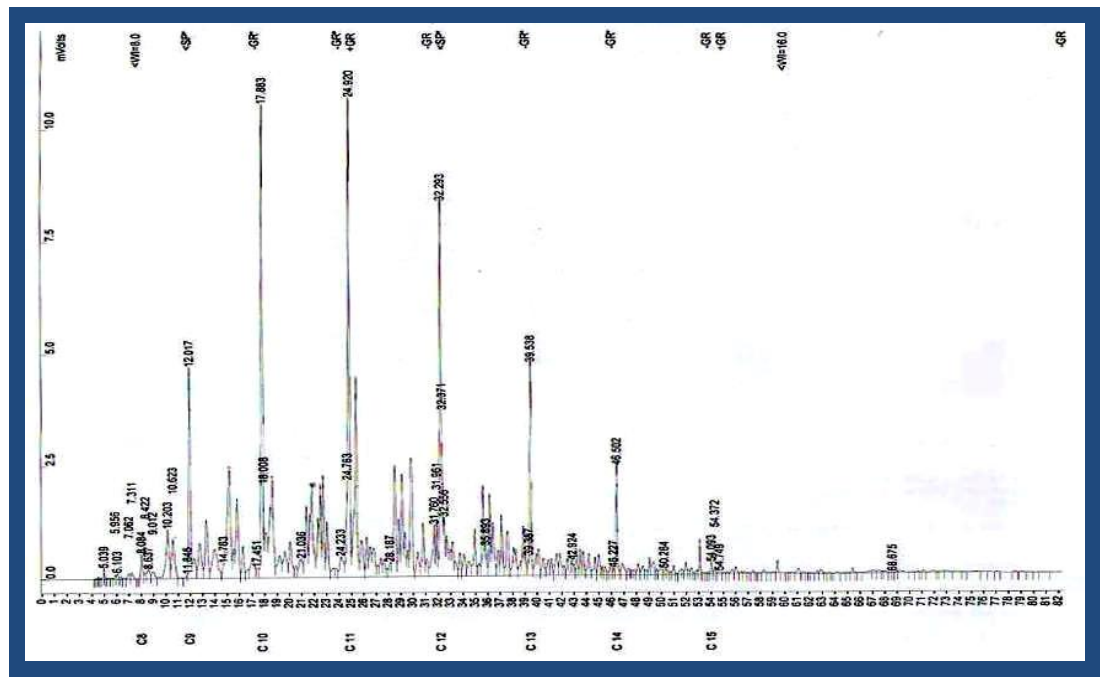

Figure 4: Gas chromatography spectra of untreated kerosene sample. 